\title{
610 JANUARY: POLITICAL CALCULATION OR RESPONSE TO A SOCIO-ANTHROPOLOGICAL REQUIREMENT IN BENIN?
}

\section{Jean-Baptiste Sourou ${ }^{1}$}

In Benin, on 10 January of each year, the annual festival of traditional religions is celebrated. The institution of this date was promulgated on 20 August 1997 by President Mathieu Kérékou. This is Law No. 97-031 of 20 August 1997, which was previously deliberated and adopted by the National Assembly. The law is a first in Africa, if not in the world. Under the law, traditional religions, have their holiday, paid and unpaid, following the example of the great Christian and Muslim religious festivals, which were the subject of a law enacted seven years earlier, on 18 July 1990, by the High Council of the Republic, the transitional parliament. That law was the Law No. 90-019 of 27 July 1990.

Far from being unanimously endorsed, the institution of this feast of the traditional religions has been much criticised. On the one hand, it would consecrate the resurgence of ancestral practices, sometimes occult and opposed by the Christian faiths (Catholic, Protestant and especially Evangelical) as well as Muslims during the revolutionary period in Benin. ${ }^{2}$ On the other hand, it was simply the result of pure political calculations to attract the votes of a large number of voters, since the traditional cults - in particular, the Vodoun - remain very anchored in the morals of good number of Beninese.

The purpose of my research is to analyse and assess these matters. Is 10 January the fruit of pure political calculations, or is it a response to a social and anthropological demand with the intention of rehabilitating these traditional cults and their arts, their Beninese and global heritage and to allow the many Beninese followers of these cults celebrate their community and social identity publicly like the believers of other religions in democratic and secular countries? Contemporary and historical actors in Benin can help us to identify, analyse the facts and draw the necessary conclusions. This study necessarily begins with a detour through the Ouidah 92 Festival in Benin.

\section{OUIDAH 92 FESTIVAL: AMERICAS-AFRICA HOMECOMING}

From 8 to 18 February 1992, the first Americas-Africa Homecoming Festival took place in the coastal town of Ouidah in Benin. For ten days, personalities from

1 Professor of Communications, Saint Augustine University of Tanzania; Founder and President, Center for Documentation and Research on Art and Social Sciences, Republic of Benin.

2 Sourou JB. 2016. "State and Religion under the 1977 Constitution in Benin", in Coertzen P, Green MC and Hansen L (eds). Religious Freedom and Religious Pluralism in Africa: Prospects and Limitations. Stellenbosch: African Sun Media, 29-35. 
the world of culture, arts, research, as well as politicians from Benin, Africa, Europe and especially the Americas (USA, Haiti, Brazil and other Caribbean countries) met for a "manifestation of memory, an appropriation of this tragic page of our collective destiny as the slave trade". ${ }^{3}$ It was an occasion for the indigenous people and Africans of the diaspora and descendants of the victims of the Atlantic slave trade to meet together in the same places where some gave up their brothers and where others left for a tragic adventure, to look at each other, to do a work of memory, to go beyond the past and to seek together what could unite them in spite of the betrayal, the shame, the inevitable resentments that the treaty has generated for several centuries. According to Nicéphore Soglo, then president of Benin, Ouidah 92 was "also an invitation to weave active solidarity with the descendants of those who survived the ordeal and with whom we want to live our community of destiny fully".

In the same speech, President Soglo highlighted the role of traditional religions in maintaining a common identity between the Africans who remained on the continent and those trafficked by detainees. He said, "It is easy to see that traditional religions, 'vodoun' in particular, formed the framework of the culture of the black peoples of the diaspora, the element that allowed them to safeguard their identity in a universe of physical, economic and cultural degradation. As for the Africans who remained on the continent," he continued, "it was in the same way that they learned their survival under foreign occupation. While the powerful machine of the colonial administration carried out its pitiless wager in the condition of the conquered territories," President Soglo explained, "it was still through the sources of cultural tradition that the movement of refusal, arising in different parts of the continent, drew its mobilizing force and the means of its organization ... The ancestral culture thus presents itself as the natural link between the black peoples scattered throughout the world," he concluded. In sum, beyond all, physical distance, centuries and sufferings of all kinds, the peoples of Africa and the diaspora have an important element that unites them, brings them together and maintains them in a communion of identity. It is traditional religion, Vodoun worship, in particular. And this is what Ouidah 92 wanted to highlight as the basis of a true reconciliation and as a springboard to forge more fraternal bonds that will mark a new era in the relations between Africans on the continent and the diaspora.

For his part, the philosopher and former Benin Minister of Culture, Paulin Hountondji declared, concerning the place of religion in the preservation of the identity of deported Africans, that "of all possible forms of cultural identification, religious identification is the most spectacular. The vitality of the 'vodoun' cult in Haiti and the cult of the 'orisha' in Brazil is proof of this. It is known that the Haitian 'vodoun' is the heir of the 'vodun' cults of South Benin and South Togo and that the cult of the 'orisha' is inherited from

3 Soglo N. 1993. "Ouidah 92 est avant tout une manifestation du souvenir" [Ouidah 92 is above all a manifestation of memory], La Nation, 10 February:3. All quotations in this paragraph and the next are taken from this source. 
the Yoruba cultural area in South Nigeria and South Benin. Thus," he observes, "in these diaspora communities, there is a fierce desire to preserve ancestral religion or to recreate it, a passionate effort to keep alive this tradition that saves them from anonymity more accurately and gives them their own personality. Identification of self through identification with a collective imagination: one must understand this process and recognise it in what it has legitimate."4 Clearly, in the view of President Nicéphore Soglo and his Minister of Culture, the role played by traditional religion was undeniable in past centuries in terms of the consolidation of the two African peoples. It can continue to occupy this place in both communities: local and diaspora. And if Africa has something noble to offer to the world of the twenty-first century, it can only be through a recovery and appropriation of the values of its traditional religion.

It is understandable that in order to celebrate the "Americas-Africa reunion", a special emphasis has been laid on this important element, the substance that has united the two continents over the centuries: traditional religion. Traditional African religion is not limited to vodoun or orisha and similar manifestations, but it is a container whose cults are contents. To borrow mathematical language, one would say that the traditional religion is the whole and the Vodoun, Orisha, Shango and other spirits are the elements. "To try to understand Africa and the African without the contribution of the traditional religion would be like opening a large cabinet emptied of its precious content," said the philosopher and anthropologist from Mali, Amadou Hampaté Bah. ${ }^{5}$

In Africa, religion is omnipresent and affects all areas of the individual's life from birth to death and through the various stages of life: initiation to adulthood, marriage, failures, important decisions, illnesses, funerals. The whole life is explained by the crucible of an attachment to the Creator, the spirits and the ancestors. By letting his daily life permeate by the presence of the sacred, the African grounds a cosmovision, an anthropology, a culture. Hence arises a plastic art, music, dance, literature, theatre. For "African religion is a cultural religion; African culture is a religious culture". ${ }^{6}$ The reference to traditional religion is strong in the African culture - it is its most valuable defense and attack weapon.

As a whole, Ouidah 92 also sought ways for the promotion of traditional culture, including traditional religion. With the Ouidah 92, a movement of reconquest and reappropriation of a traditional culture, which goes beyond the physical limits of Benin and Africa and which unites millions of people all over the world took form. But this reconquest cannot be achieved without state support

4 Hountondji P. 1992. “Le ministre de la culture déclare: ‘Non, les cultures du Bénin se sont pas de cultures du Vaudou'" [The Minister of Culture declares: "No, the cultures of Benin are not cultures of vodoun"], La Nation, 27 November:5.

5 Bah AH. 1965. Textes sacrés d'Afrique noire [Sacred texts of black Africa]. Dieterlin G (ed). Paris: Gallimard, 8.

6 Tossou R. 1977. Presentation to the Pan-African Conference of Theologians of the Third World, Accra, Ghana. 
and without a favourable legal framework. During the revolutionary period in Benin, religions as a whole, especially traditional religions, experienced a difficult period, if not outright persecution. But the democratic wind that has blown on Benin from the National Conference of Living Forces in February 1990 and the further establishment of the rule of law promoted the will "to give substance to the permanent quest for identity of the black man". ${ }^{7}$ It is in this climate, in fact, that Ouidah 92 was able to stand.

\section{DEMOCRACY IN BENIN: SECULARISM OF THE STATE}

The Beninese Constitution of 1990 stipulates in Article 2 that the Republic of Benin is secular and democratic. Article 23 states that the exercise of worship and the expression of beliefs are carried out within the framework of state secularism. In the second paragraph, it is written: "Institutions, religious or philosophical communities have the right to develop without hindrance." This is quite contrary to the Basic Law of $1977 .{ }^{8}$

It was in the climate of the democratic era that Law No. 90-019 of 27 July 1990 was promulgated, designating legal holidays, both paid and unpaid, in Benin. The Christian Churches have six holidays: 15 August, Day of the Assumption; 1 November, All Saints Day; 25 December, Christmas Day; as well as Easter Monday, Whit Monday and Ascension Day. The Muslim community has three holidays: the day of Ramadan, Tabaski Day, ${ }^{9}$ and the Day of Maouloud..$^{10}$ Until then, traditional religions had no officially recognised feast day.

It is, in fact, this secular character of the Republic of Benin on which the organisers of Ouidah 92 relied to justify the holding of the festival and the place they accorded to the traditional religions. Such a festival could not have seen the light of day in the days of the Marxist-Leninist revolution in Benin between 1972 and 1989. "Secularism, of course, requires the state to stand at an equal distance from all beliefs and confessions,"11 said President Soglo during the closing ceremony of the festival. "Nevertheless," he continued, "neither did we feel that we were breaking this rule by receiving with joy and fervor his

7 Soglo N. 2013. "Pourquoi la fête des religions traditionnelles au Bénin? Les explications du Président-Maire Nicéphore SOGLO" [Why a festival of traditional religions in Benin? The explanation of President-Mayor Nicéphore SOGLO], Jolome News. Online at: http://bj.jolome.com/news/article/pourquoi-la-fete-desreligions-traditionnelles-au-benin-les-explications-du-president-maire-nice-336

8 Cf. Sourou, "State and Religion under the 1977 Constitution in Benin".

9 Eid al-Adha "Festival of the Sacrifice", also called the "Sacrifice Feast", is the second of two Muslim holidays celebrated worldwide each year, and it is considered the holier of the two. It honours the willingness of Ibrahim (Abraham) to sacrifice his son, as an act of submission to God's command.

10 This is Prophet Muhammed's (also known as Mohammed or Muhammad) birthday.

11 Soglo N. 1993. "Il nous faut jeter les passerelles nécessaires entre les communautés noires des Amériques et de l'Afrique" [We need to build the necessary bridges between the black communities of the Americas and Africa], La Nation, 22 February:5. 
Holiness Pope John Paul II. ${ }^{12}$ Did not believe we betrayed this duty of neutrality by going to meet Beninese and African religions. The rest is just a matter of words. We must now go beyond any vain polemic and underline the essential convergences."13

\section{JANUARY: POLITICAL CALCULATIONS?}

The organisation of Ouidah 92 has prompted gnashing of teeth in several religious spheres in Benin. Many feared that it was a mock cultural event to promote the Vodoun and other cults. ${ }^{14}$ President Soglo alluded to it in his closing speech. Another fear was the fact that traditional cults also sometimes include manifestations that are not respectful of human rights: forced internment in convents, abusive marriages, witchcraft, unorthodox rituals and entanglements. Such behavior violates the integrity of the human person on the one hand, and the Constitution of Benin 1990, ${ }^{15}$ on the other. The Catholic Church and other religious communities have struggled and struggled in Benin as pretty much everywhere else in Africa. Their fear is well and truly justified.

In the literature I consulted for this research, it appears that Ouidah 92 was not the result of political calculations. Some argue that Soglo's illness, which occurred shortly after his election as head of the country in 1991, brought him closer to traditional healers and enabled him to appreciate the importance of culture and Traditional religions. ${ }^{16}$ It should also be borne in mind that Ouidah 92 was organised by Soglo in 1993 and that the law instituting the Feast of Traditional Religions was passed by parliament and promulgated in 1997 by Mathieu Kérékou, whose election in 1996 was not very much supported by his predecessor.

\section{CONCLUSION}

Without sweeping aside the conclusions of Cédric Mayrargue, I believe, based at least on the sources that I have consulted, that the real reasons for the institution of the day of 10 January in Benin can be found in the firm will of the organisers of Ouidah 92 - namely, to "celebrate together with the Diaspora the

12 Pope Jean-Paul made a pastoral visit to Benin for the second time from 3 to 5 February 1993, a week before the opening of Ouidah Festival.

13 Soglo, "Il nous faut jeter les passerelles nécessaires", 5.

14 Soglo, "Il nous faut jeter les passerelles nécessaires".

15 Cf. Articles 15, 16 and 18, para 1. In particular, Article 15 reads: "Everyone has the right to life, liberty, security and the integrity of his person."

16 Mayrargue C. 1997. "Démocratisation politique et revitalisation religieuse, l'exemple du culte vodun au Bénin" [Political democratistion and religious revitalisation, the example of the Vodoun cult in Benin], in Constantin F and Coulon C (eds). Religion et transition démocratique en Afrique [Religion and democratic transition in Africa]. Paris: Editions Khartala, 135-162. 
density and humanistic value of traditional religions, the foundation of African spiritualism ... to give substance to this permanent quest for the identity of the black man. On this land of nourishment and steeped in history and culture ... after four centuries of slave trade and a century of colonisation that had blackened the black man, time had finally come to claim with Aimé Césaire and Léopold Sédar Senghor, our personality, our dignity and our negritude. For an enslaved and colonised soul cannot be carried on indefinitely. We must be proud of our culture, our history, our people, our race."17 Soglo said recently, "Africa, the cradle of humanity and the source of its origins, is a land of welcome, a land of tolerance and respect for differences." ${ }^{18}$ And these values undoubtedly come from African traditional religion, understood as a culture that has shaped, nourished, maintained and consolidated the unique identity of the peoples of Africa throughout the centuries. There are actually some ways of seeing the world that we find only on our continent.

The great Pope John Paul II, during his second visit to Benin recognised the importance of this during his meeting in Cotonou with the leaders of traditional religion, ${ }^{19}$ when he declared, "It is legitimate to be grateful to elders who have transmitted the meaning of the sacred, the belief in a unique and good God, a taste for celebration, esteem for moral life and harmony in society." ${ }^{20}$ Then the two synods devoted to Africa in 1994 and 2009 largely reversed the role and place of traditional African religion in the formation and maintenance of a Christian conscience in Africa. ${ }^{21}$

Soglo emphasises,

This position on traditional religions in our policy, is only fair, not only are these religions practiced by a large part of the Beninese population, they are a real factor of identification, understanding and integration. The foundation of this strength lies in the deeply pacifist nature and the exceptional open-mindedness of our endogenous religions. They do not engage in any proselytism and do not engage in any war against other religious denominations, except to defend themselves against the attacks to which they have been subjected..$^{22}$

Those who seek at all costs to condemn the Ouidah 92 initiative and the institution of the National Feast of Traditional Religions also show, in my

17 Soglo, "Pourquoi la fête des religions?"

18 Soglo, "Pourquoi la fête des religions?"

19 I believe, without deceiving myself, that this is the only meeting of the kind that John Paul II had during his whole pontificate.

20 Pope John Paul II. 1993. "Rencontre du pape Jean-Paul II avec une délégation des disciples du vaudou" [Meeting of Pope Jean-Paul II With a delegation of vodoun disciples]. Online at: http://w2.vatican.va/content/john-paul-ii/fr/speeches/1993/ february/documents/hf_jp-ii_spe_19930204_vodu-cotonou.html

21 Sourou JB. 2014. "African Traditional Religion and the Catholic Church in light of the Synods for Africa: 1994 and 2009", African Human Rights Law Journal 14(1):142-149.

22 Soglo, "Pourquoi la fête des religions?" 
opinion, a certain lack of knowledge of the geography of religions. If all the peoples of this world have their religion, why should Africans not have theirs? And, yet, among those who fight initiatives like 10 January can be found many Beninese and Africans. All peoples of the world are committed to their cultures, their traditions and their religions. This is true of Shintoism in Japan, Confucianism in China, Buddhism in India, Christianity in Europe (if there is anything left of it) and Islam in the Middle East. And we in Africa where is our religion? What have we done? And what do we want to do?

I think that modern Africa - without hiding behind scientific progress and its achievements and without any shame, if it wants to preserve its soul, its lucidity and its genius - must return to traditional religion, to its cradle, to its true values, and think that even in the face of the problems of today's world. lies its strength, vigour, sap and progress in all fields: political, scientific and cultural. 